\title{
Possible Assessment Method of Green Infrastructure in the Case of Small Town Keszthely, Hungary
}

\author{
Vera Iváncsics ${ }^{1} \&$ Krisztina Filepné Kovács ${ }^{1}$ \\ ${ }^{1}$ Department of Landscape Planning and Regional Development, Faculty of Landscape Architecture and \\ Urbanism, Szent István University, Budapest, Hungary \\ Correspondence: Vera Iváncsics, Department of Landscape Planning and Regional Development, Faculty of \\ Landscape Architecture and Urbanism, Szent István University, Budapest, Hungary, Villányi út 35-43, K Building, \\ H-1118, Budapest, Hungary. Tel: 36-1-305-7291. E-mail: ivancsics.vera@phd.uni-szie.hu
}

Received: September 5, 2020 Accepted: September 28, 2020 Online Published: October 27, 2020

\begin{abstract}
Recently the planning of green infrastructure (GI) has become a general practice around metropolis (Paris, München, Budapest, etc). A complex methodology is required that goes beyond the scope of traditional green surface systems. However, there are various policy implications in the EU, the smaller towns are lagging to apply them. The paper presents a potential evaluation method through the case study of Keszthely, HU. As Keszthely at Balaton Riviera, is a popular touristic target of CEE, the environmental planning is an essential part of sustainable development.

After a literature analyses of assessment methods of GI and ecosystem services, the aspects of GI have been valued on grade scales, based on field surveys and indicators. The current status of the GI was surveyed which is a base for further development and monitoring activities. The paper introduces the methodology, which contributes to preservation of ecosystems.
\end{abstract}

Keywords: GI assessment, ecosystem service assessment, Keszthely, Balaton, evaluation, tourism

\section{Introduction}

The issue of green infrastructure (GI) is more and more often faced during development of settlements, although usually only minor investments (e.g. green roofs) are associated with it. Such developments do raise awareness, but could be truly efficient if a proper strategy is connected to them. Several such strategies are known on international level (Davies et al. 2010, Naumann et al. 2011, European Green City Index), and despite of a number of good practices, this field is in its infancy in Hungary. In our work, the city of Keszthely has been selected as an example to elaborate proposals for a greener settlement. When developing the evaluation methodology, experience of multiple fields was gathered, such as professional surveys, international practice, national recommendations and needs of the city council. The created cadastral database can be further developed and is able to support acrossthe-broad strategic planning and development of the city's future, which foster both the improvement of ecological quality and socio-economic goals.

GI is a relatively new terminology, although similar ones are found in Hungarian literature as well. Green space systems (Jámbor, 1982) cover parks, protection forests, certain land use types and forests. The green network concept of Balázs Almási (Almási, 2007) extends this, including all areas with vegetation. The idea of GI, however, is more complex than these early Hungarian definitions. The first introduction of GI in Hungarian literature was given by Béla Oláh András (Oláh, 2012), which was followed by a more extensive definition, given by the Green Infrastructure Development Reservation and Guide, published in 2016: "GI are those strategically planned networks of natural and semi-natural areas and other vegetational areas serving ecological purpose, which are planned and directed in a way to be able to supply a wide range of ecosystem services. Main elements of GI are green areas ("green elements") and water surfaces ("blue elements"). GI can complement or occasionally replace technical ("grey") elements of the infrastructure, like roads, canals, utility lines, equipment and buildings. GI functions as a network enabling the flow of material and energy and securing the supply of those. In another way, GI is a conceptional approach, which aims to provide ecosystem goods and services in an integrated way (through protection and development of ecosystem elements and their connections), decreasing environmental and climate risks, thus helping to retain of population. 
Various approaches are seen in the literature as well, having the common feature that GI is a network, which includes elements of natural and near natural areas (Seiwert and Rößler, 2020). Most of the definitions also highlight the necessity of preserving the quality of the ecosystem (EC, 2012, 2013), however those can be concurrent with ecosystem services with the society (Artmann et al., 2017; Lindholm, 2017; Schröter-Schlaack and Schmidt, 2015; Sylwester, 2009; Karhu, 2011).

Some definitions consider GI as a multifunctional resource, providing goods and services. These goods play a role in preserving the quality of life, environment and natural elements, but also contribute to job creation. Certain definitions emphasize the ability of GI to replace or complete artificial infrastructural elements. Connection of urban and rural areas and sustainability are only seen in a couple cases, although this is an important addition of the GI concept to its predecessors (The Landscape Institute, 2009; Amati and Taylor, 2010; Naumann et al., 2011). The cause may be hidden in the question of different scale and land use types (Bartesaghi et al., 2016). In summary, the Hungarian concept of green space systems is not a perfect match for the concept of GI; the wider frame of thought is explained in the following.

- GI definitions are not solely based on the elements, but on the importance of interactions between near-natural areas and the society: they consider service capability, economic significance and sustainability (McMahon and Benedict, 2002; Benedict and McMahon, 2006; DCLG, 2008a; DCLG, 2008b; Natural England, 2009; CABE and Natural England, 2010; Naumann et al., 2011; EC, 2012; EC, 2013)

- Focus of examinations does not only consider vegetation, but water surfaces and artificial infrastructure elements are also included. (CABE and Natural England, 2010; Davies et al., 2010; Naumann et al., 2011; EC, 2013; Mell, 2017)

- Definitions often highlight the importance of the quality/status (e.g. air quality, water quality) of natural elements. (TCPA, 2008; Siemens, 2012; Natural England, 2009; Siemens, 2009 Gill et al., 2009).

- The networks are constructed from both point-like and extensive areas, depending on their location and function. (Opdam et al., 2006; Natural England, 2009)

- Thinking in network, its aim is the development of the network (McMahon and Benedict, 2002; Benedict and McMahon, 2006; Opdam et al., 2006; DCLG, 2008a; DCLG, 2008b; Natural England, 2009; CABE and Natural England, 2010; Naumann et al., 2011; EC, 2012; EC, 2013; Reimer and Rusche, 2016).

There is also a tight connection between the concepts of GI and ecosystem services, which include all services and goods provided for the society by the nature and biodiversity. These include amongst others the ecological basis of healthy food, clear freshwater and clear air, habitat, pharmaceutical ingredients, the role played in avoiding or mitigating the effect of natural disasters, epidemics and diseases, and climate control (CBD, 2015). This concept embraces aspects of ecology and social sciences as well, thus providing an excellent support for policymaking.

As it can be seen from the previous brief overview, existing definitions allow a broad interpretation; in the paper only green and blue infrastructural elements were considered. After identifying the GI elements, they were evaluated as ecosystem service providers in order to develop proposals which can serve the development of both the local environment and the local economy. The conceptual frame used in the work can be summarized as follows: GI is a resource, which provides ecosystem services. These goods play or can play a role in preserving or improving the quality of life, environmental and natural elements, and supporting economic growth. Identification of GI elements (scale, size, functionality or role) is primarily determined by development goals. The elements form a network, which provides the connection between natural and near-natural areas. Development of urban GI considers the characteristics of the area, the needs of locals and contributes to the formation of a more sustainable environment.

\section{Methods}

In this section various methodologies are presented and compared, which are all designed to characterize GI services. During the work, besides literature, special emphasis was given to the national guide released in 2016 (Manual for Development and Maintenance of Green Infrastructure, 2016), to develop a methodology that suits both international and national legislations.

After defining the conceptual frame, characteristics of the administrative area of Keszthely and the institutional background was reviewed. A list of areas was prepared, which are of outstanding importance due to traditional or everyday use or are subject of future development. (5t and HÉTFA, 2015; Varsás, 2017; Koller, 2001; Szabó, 2013) Afterwards, GI elements forming the GI network were identified and grouped according to their types (tree, tree alley, park and extended green area, surface water and urban fabric); their digitalization in Geographical Information Systems-GIS (ArcMap) was carried out using Google Earth records and the base map of the city in 
vector dataset. Field surveys were carried out in July and August 2016 in order to identify new elements and to clarify earlier records, and interviews were organized with professionals, municipal employees and locals.

Evaluation was carried our along multiple aspects (ecological quality, aesthetics, ecology services and usability) to integrate ecological and social proposals. Indicators were defined for the elements (see Table 1.), and ratings were assigned after the field survey on 3 or 5 grade scales. Quality characteristics of the outlined network were evaluated, and SWOT analysis was carried out to summaries main experiences. The elaborated proposals include more and more detailed interventions from the GI network to GI elements (Figure 1). The methodology has later served as a basis for the Green Infrastructure Development and Maintenance Action Plan of Keszthely (HÉTFA Research Institute, 2017).

\subsection{Possible GI Examinations}

Two methodologies were identified in the literature to characterize cities from the aspect of their GI, which emphasizes either the elements of green and blue infrastructure and the quality of ecological services. Other notable aspects to consider:

- characterisation of green and blue infrastructure elements (GI elements) (Jombach, 2014)

○ based on scale/size, e.g. local, urban, regional (The Landscape Institute, 2009)

○ naturalness (Naumann et al., 2011)

○ type of elements e.g. gardens and parks, pleasant green spaces, natural or near-natural urban green spaces, green corridors, community gardens, cemeteries, churchyards (Natural England, 2009)

- measurement of the quality of ecosystem services (GI functions) (CABE and Natural England, 2010)

○ according to environmental factors (Siemens, 2008; Siemens, 2009)

$\circ$ based on the opinion of locals and investors enjoying the benefits of ecological services (McDonald et al., 2005; Natural England, 2011)

- monetizing the value of services (Tajima, 2003; Naumann et al., 2011; Mell et al., 2013)

- $\quad$ mixed evaluation methods (McDonald et al., 2005; TCPA, 2008; Natural England, 2009; EEA, 2014), like the European Green Capital system. The essence of these methods is to examine the elements using separate aspects and then evaluating ecosystem services based on environmental elements, human aspects or the monetization of services. Conclusions are drawn in two different ways.

Because of the above listed aspects, it was important to develop a methodology which is capable of handling both GI elements and the network. It was also an objective to support the strategic decision-making of the municipal in the future as well through the analysis and evaluation process. Consideration of the organic and direct connection between society and its natural environment was crucial to develop proposals, that are useful from a societal perspective. Finally, it was important to create a database that is compatible with GIS, providing basis for future development and the evaluation of results.

The applied methodology was a mixed one that incorporates several aspects of above mentioned literature, optimized in light of the specialties of urban areas and the guide for GI (Figure 1).

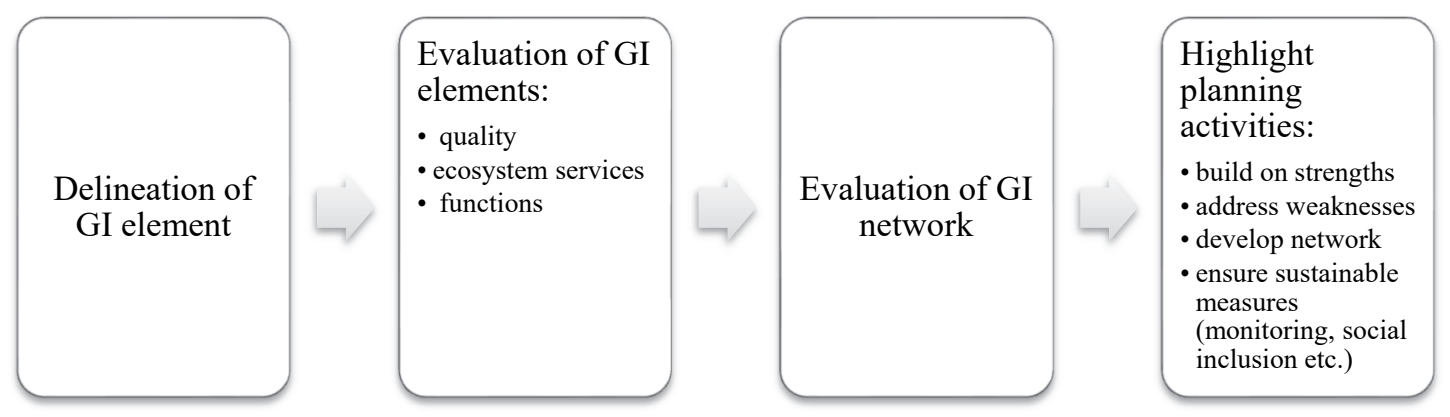

Figure 1. Flowchart of the applied methodology 
Quality of GI elements and ecosystem services were both considered, and two methods were used during the evaluation process: one by one ranking of GI elements and collective ranking of urban arrays were performed. Quality criteria, ecosystem services and functions were examined for each GI element, then they were summarised to evaluate the whole GI network. Quality criteria were evaluated according to separate methods for each group (tree, tree alley, green space, surface water, urban fabric)

Ecosystem services were evaluated using an own method, based on the one published by Koscke et al. (Koschke et al., 2012), verifying the existence of six functions. These groups were formed based on the groups defined by the Millennium Ecosystem Assessment (2005) in a way that resulting categories can be easily understood by local players and stakeholders. This system is different from the widely used cascade model (Haines-Young and Potschin, 2009), Common International Classification of Ecosystem Services CICES-V4-3 2013), which eases cooperation with multiple social players. Indicators of the Koschke et al. (2012) study were adapted to Hungary, while rating with scales were kept unchanged. In summary, the developed methodology, the applied examination and evaluation frame, the simultaneous application of various aspects are own contributions, which are suitable for international and national practice and the characteristics of Keszthely, and provide results, which are easier to interpret for the stakeholders.

\subsection{About Keszthely}

The study area is Keszthely (Figure 2) town with its administrative area of $76 \mathrm{~km}^{2}$ and 19289 inhabitants (Hungarian Central Statistical Office, 2019). It is located in Central Eastern Europe, Transdanubian region of Hungary at the shoreline of Lake Balaton, and in the neighborhood of Hévíz spa, both popular touristic destinations of international audience. Its natural values are unique, because of Keszthely mountain and buttes nearby and Balaton natural protected area. The cultural heritage also remarkable, heritage fortress from Roman Empire and Festetics Castle. However, the town is an important target of visitors its population is shrinking, like most of Hungarians.

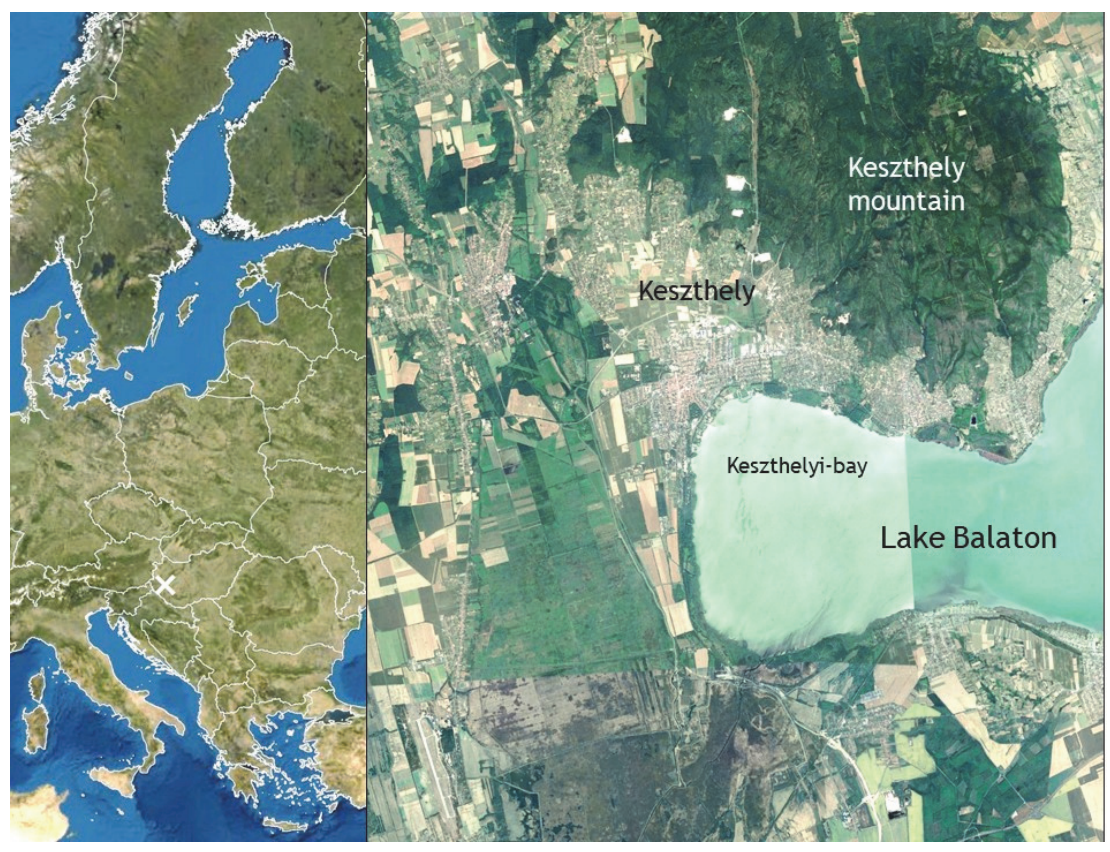

Figure 2. Map of Keszthely (Source: Google Earth)

\subsection{Adapting GI methodologies to the City of Keszthely}

The identified GI elements were digitalized using GIS-ArcMap software 10.2.2., to create a database for later use as well. A fully detailed map, provided by the city council, was used during this process, so that existing parcel allocation could be considered. Grouping of various GI elements was carried out according to suggestions of the literature and the characteristics of Keszthely, in the following way:

- Tree: point-like element. The need for a tree cadastral database was identified during the interviews with municipal employees, thus the methodology for examining and evaluating trees was incorporated in the work. 
- Tree alley: linear element, corridor of the GI network

- Park or extended green area: possible centres of GI

- Water elements: water surfaces, which could be linear (watercourses) and two-dimensional-surface (lake Balaton) by their nature.

Simultaneously, an analysis of urban fabric was performed, which included the above listed elements; important elements of the GI network are the green areas of private gardens and yards, which have been identified on array level along the roads, with more detail (in blocks) in downtown and less (in group of blocks) in outer downtown. Results of this examination are shown in Table 1.

Table 1. Applied delineation and data for description of green infrastructure element

\begin{tabular}{|c|c|c|}
\hline GI elements & Delineation & General data collected during the examination \\
\hline Tree & $\begin{array}{l}\text { Notable trees: trees under local } \\
\text { protection based on the database of } \\
\text { dendromania.hu } \\
\text { Cadastral database }\end{array}$ & $\begin{array}{l}\text { Type and location of the element, name of public } \\
\text { domain, year of last recorded development, species } \\
\text { and subspecies, trunk circumference, canopy } \\
\text { diameter, height }\end{array}$ \\
\hline Tree alley & $\begin{array}{l}\text { Tree alleys under local protection or } \\
\text { having cultural significance, other } \\
\text { important tree alleys identified by } \\
\text { field surveys and Google Earth } \\
\text { records }\end{array}$ & $\begin{array}{l}\text { Type and location of the element, name of public } \\
\text { domain, year of last recorded development, typical } \\
\text { species }\end{array}$ \\
\hline $\begin{array}{ll}\text { Park } & \text { or } \\
\text { extended } & \\
\text { green area } & \end{array}$ & $\begin{array}{l}\text { Green surfaces and other important } \\
\text { green areas identified by field surveys } \\
\text { and Google Earth records }\end{array}$ & $\begin{array}{l}\text { Type and location of the element, name of public } \\
\text { domain, year of last recorded development }\end{array}$ \\
\hline Water surface & $\begin{array}{l}\text { Water surfaces based on national river } \\
\text { basin management plans }\end{array}$ & $\begin{array}{l}\text { Type and location of the element, name of public } \\
\text { domain, year of last recorded development, type and } \\
\text { description of water surfaces, existence of grey } \\
\text { infrastructure, watershed area, planned interventions }\end{array}$ \\
\hline Urban fabric & $\begin{array}{l}\text { Urban arrays in downtown (so-called } \\
\text { City Centre Action Area-CCAA), } \\
\text { group of arrays in outer downtown }\end{array}$ & Google Earth records \\
\hline
\end{tabular}

Since GI systems can have various interpretations, GI elements were evaluated using three aspects. Evaluation of the quality is informative regarding single elements, but due to their difference (and thus different methods), these elements are hard to compare. A comparison can be given though by using the conceptual frame of ecosystem services, since it not only convers ecological quality but also the relation to society and the people using these services. The GI system provided ecosystem services on a very broad palette; for easier understanding, five groups were formed. Evaluation of each function provides information purely on the use of GI, considering the viewpoint of locals and visitors. In summary, the triple structure of the evaluation supports the understanding of the following aspects:

Quality: ecological status, individual characteristics, aesthetics

Ecosystem services: integrated approach using ecological quality and socio-economic value, provides comparable characteristics

Functions: social approach based purely on the usage, provides comparable characteristics

One-by-one evaluation of the quality of GI elements allows to collect information on their status and to elaborate development proposals. Frame of quality evaluation is based on national practice, but in some cases unique methods were used. 
Table 2. Information for assessment according to green infrastructure elements

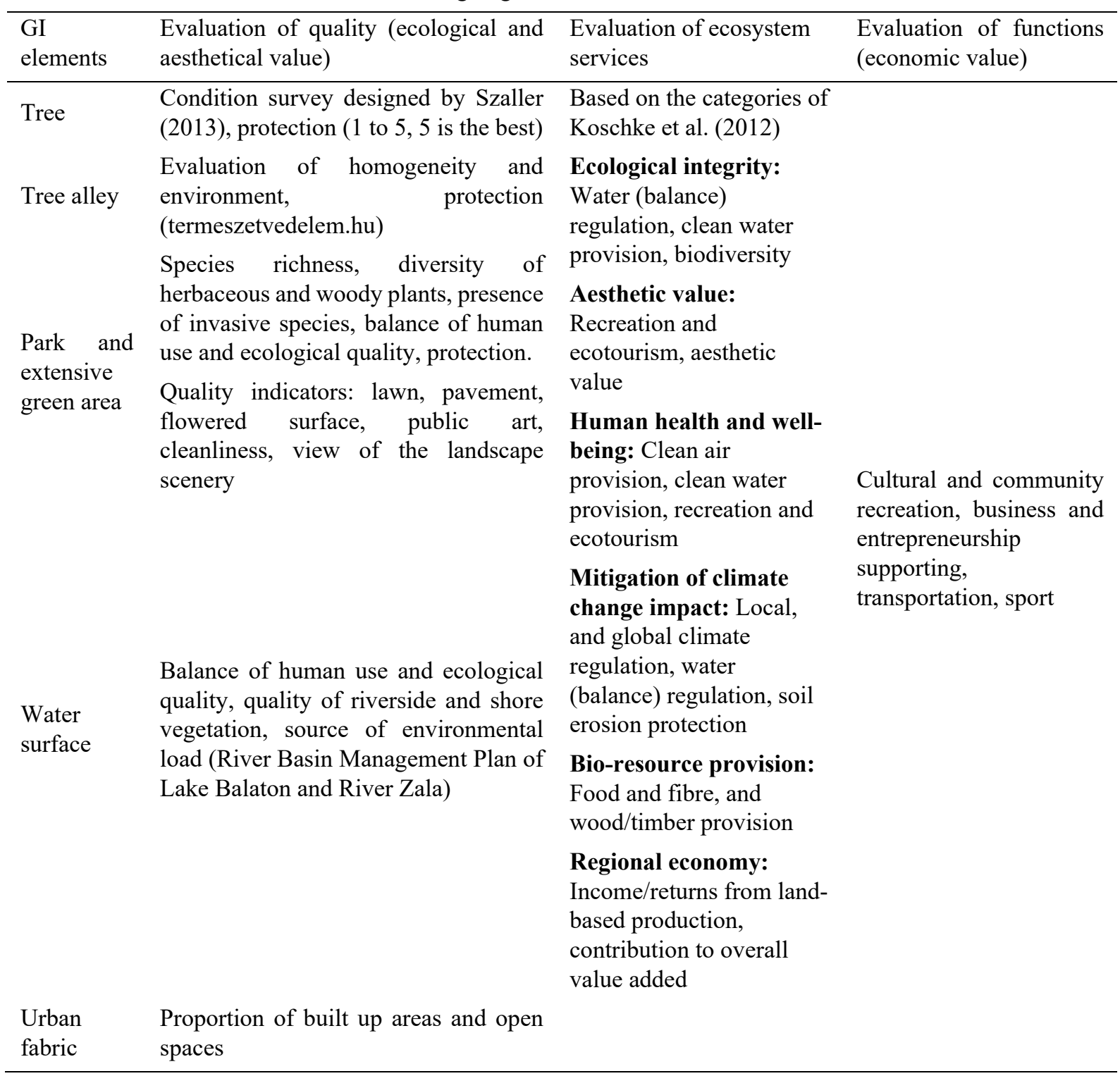

The elaborated methodology was applied to evaluate the GI system of Keszthely in order to improve the deficiencies and exploit the potentials of development. Similarly, to other Hungarian cities, Keszthely is struggling to preserve its population and to provide a livable environment to locals. The identity of Keszthely is dominantly determined by its green environment; a centerpiece of cultural heritage is the Castle park (heritage of the Festetics family), the exceptional black pine tree alley called „Fenyves allé”, the proximity of lake Balaton, or the Helikon park, which are all symbols of the city. These valuable green areas are also reflected in the development strategy and environmental protection programmed of the city. Medium-term development plans are summarized by the Integrated Community Development Strategy, which has also defined action areas, of which the most important is the City Centre Action Area (CCAA).

\section{Results and Discussion}

It was found that Keszthely possesses excellent natural conditions and several protected areas, but since its economy heavily relies on tourism, the city is vulnerable to macroeconomic effects. The proposals for the examined area are shown on the right side of Figure 1. The selected areas and arrays are those elements of urban fabric, to which the proposals were prepared for. In case of object-level planning, these are able to ensure the development of GI quality. In the following, triple evaluation of GI elements is presented for the CCAA (Figure $3)$. 

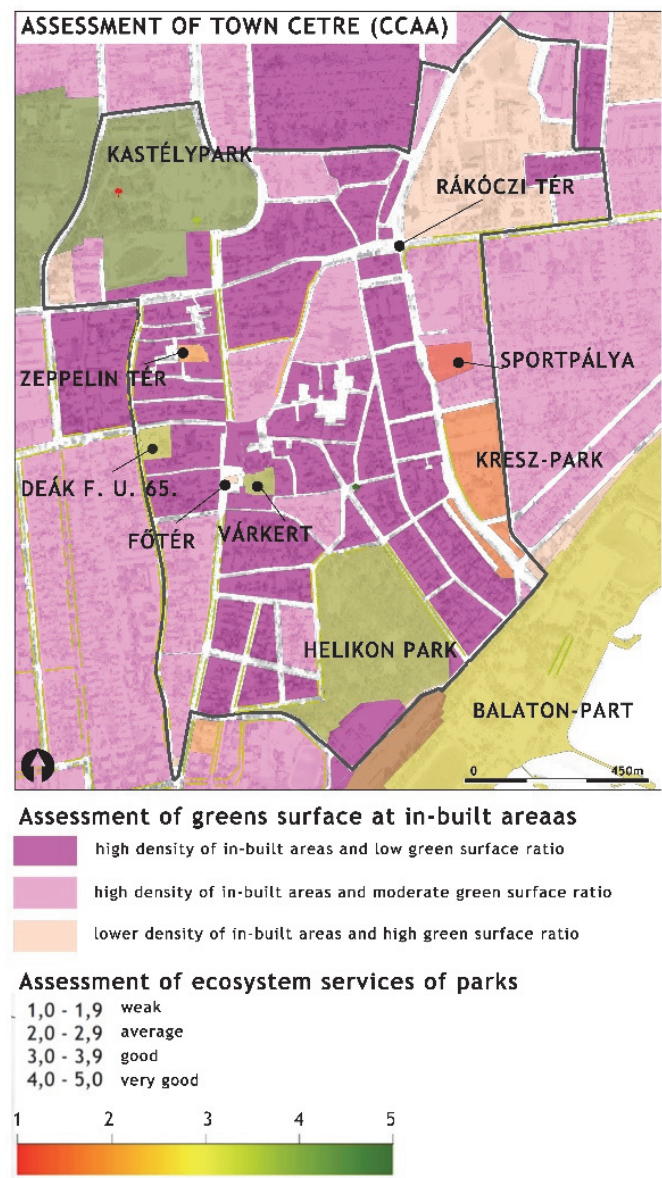

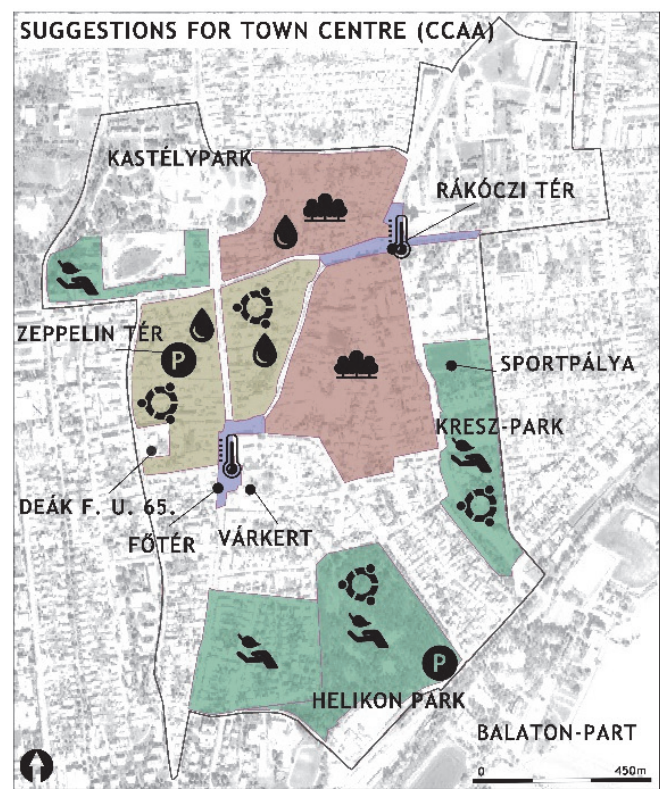

New green space to avoid heat island

- Quality development od green spaces

10 Expand functions

P Establish parking plots

Set new tree alleys, expand green surface

- Water retention

Figure 3. Assessment and recommendations for City Centre action area

(Kastélypark-Castle park, Rákóczi tér-Rákóczi square, Sportpálya-Sport track, Balaton-part-Bank of Lake Balaton, Várkert-Castle garden, Deák F. u. 65.-Deák F. str. 65, Zeppelin tér-Zeppelin square)

\subsection{Quality of GI Elements}

Status of notable trees is varying while planes (Platanus x acerifolia) and the ginkgo (Ginkgo biloba) are of good conditions, the city's oldest oak tree (Quercus robur) is almost completely dead. Environmental load of tree alleys is high, especially along busy roads; exceptions are found near the lakeside. The protected and old tree alleys along roads are typically in uniform conditions, necessary replacements are done with same species and varieties. Several deficiencies are observed on the trees of Fenyves allé, replacement of dead specimen is yet to be carried out and is made more difficult due to the variety that is rarely sold in Hungary (Figure 4). 


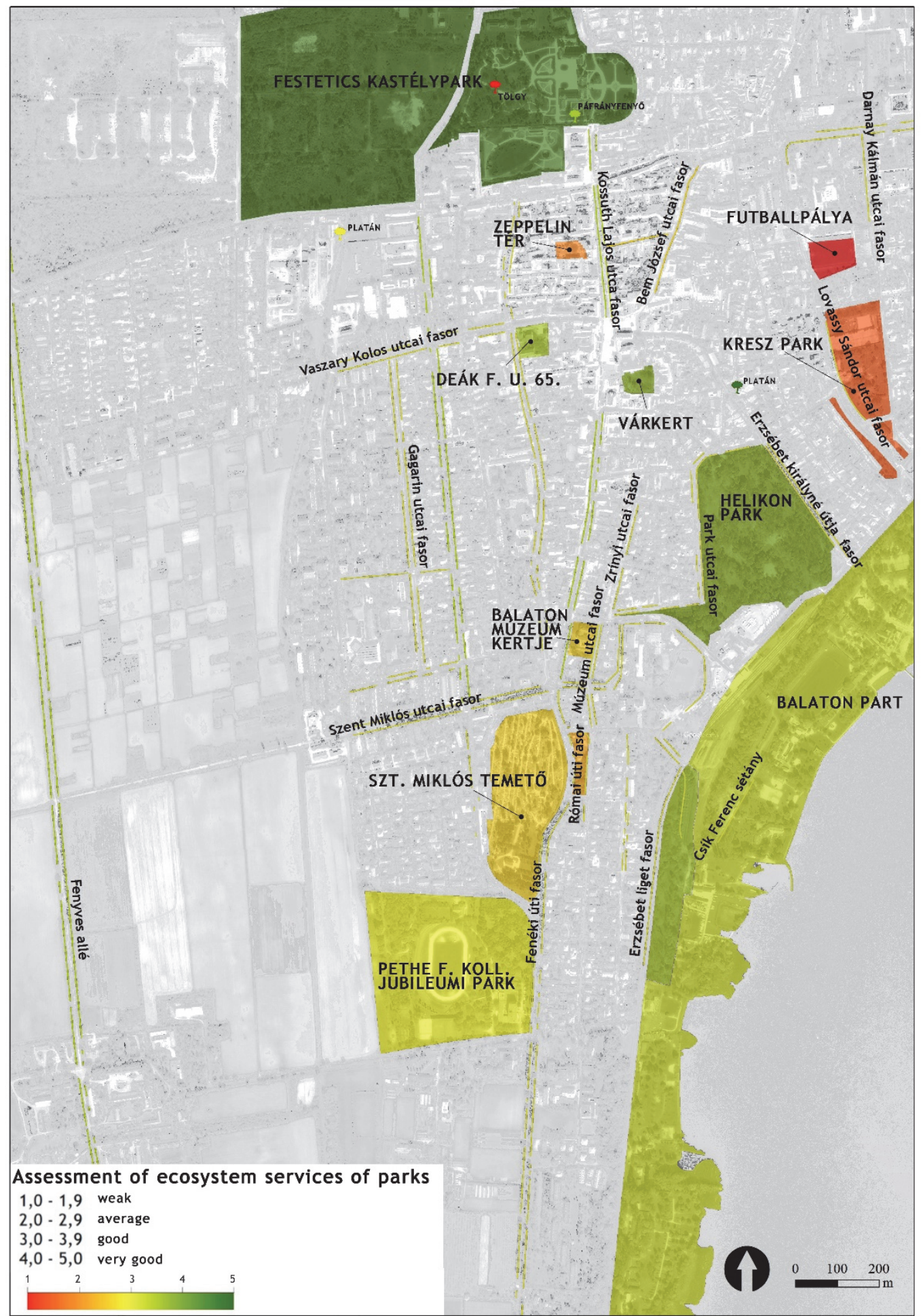

Figure 4. The assessment of extended green areas and alleys in Keszthely

(Kastélypark-Castle park, Rákóczi tér-Rákóczi square, Footballpálya-Sport track, Balaton-part-Bank of Lake Balaton, Várkert-Castle garden, Deák F. u. 65.-Deák F. str. 65, Zeppelin tér-Zeppelin square, Szt. Miklós temetőSzt. Miklós cemetery, utca-street, fasor-tree alley, allé-alley, liget-grove, sétány-alley, tölgy-oak tree, páfrányfenyő-ginkgo tree, platán-plane tree) 
The parks possess good quality lawns, tree- and shrub population. Preservation of the quality is assisted by proper selection of species and varieties, and integrated and systematic plant care. Flowered surfaces are relatively rare in the city, they are usually found on representative squares. Putting more emphasis on the use of pervious covers would also help rainwater management. The most uncared parks are out of touristic attraction and its neighborhood, while the highlights of townscape are the northern lakeside, the St. Miklós cemetery, the Castle garden and the Castle park.

Considering surface waters, overuse may pose a threat in Keszthely-bay, in Hévíz-flow and the Óberek canal.

During the evaluation of the elements of urban fabric, highlights were dominantly found in downtown, in form of squares and parks enclaved within densely built areas with low proportion of green areas. In these areas, stress of tree alleys is higher, thus not only preservation of existing population, but planting of new units is recommended.

\subsection{Level of Ecosystem Services Provided by GI Elements}

Considering ecosystem services during the evaluation as a common point of ecological and social roles was a new aspect in the examination. The results were dominantly affected by the status, location and usability of the elements, and the surrounding environment.

The results indicate that the most valuable ecosystem providers of the city are the Keszthely-bay and the connecting lakeside, the Keszthely-mountains, and the downtown parks, which are in good conditions. The highest value was given to the tree alley of Kossuth Lajos street, due to its touristic importance and the vegetation that is in good condition. From the aspect of land use, the highest values were given to the reeds, the forest and the marshlands, thus highlighting the Vadaskert among neighboring agricultural lands. Lower values were given to industrial and service areas, mines and extensive agricultural fields.

The evaluation has brought the neglected areas to the surface, which are located on the outer border of downtown. The lack of connections between valuable areas was also standing out, which could be remediated by planting tree alleys and forming park networks. Watercourses have weak usage values. Water retention is not applied in green areas, current practice aims to provide fast draining and no innovative solutions are seen. Lack of financial resources result in missed investments; quality issues and function deficits were identified. Attention was drawn to insufficiencies of tree care practice.

Two areas were identified as important ones from the aspect of ecosystem services and GI network: the marshlands at the junction of the western agricultural fields and the western lakeside of Balaton, which is located at important crossroads. The other area is found west from the Castle garden and east from Vadaspark; it consists of Dobogómajor and its surroundings. Specialty of these areas is that they show high variations of land use and ecosystem services. They are intensively used due to transport corridors, but future development of ecosystem has a great potential.

\subsection{GI Functions}

Evaluation of the functions provided the most useful results in case of parks and extended green areas, but interesting experiences were gathered in case of trees, tree alleys and surface waters as well. Functions were identified in the case of trees and tree alleys if they are located at notable or intensively used places (highway tree alleys, hundred-year-old plane tree of a famous confectionary) or if they represent cultural heritage (Fenyves allé).

The highest usage was experienced in case of the northern lakeside and the Keszthely-bay. The results are not surprising, as Keszthely relies largely on touristic incomes related to lake Balaton, thus functions are also deployed accordingly.

Several functions are assigned to Vadaskert, Helikon park, the playground at Római street and Keszthelymountains, but these can be further developed by minor function extensions. Such option is to develop entrepreneur functions of Helikon park or sport functions of Vadaskert. Similar conclusions can be drawn in relation of the Castle garden and Kresz-park, both possessing three functions.

In the areas, where two or less functions were identified, development is to be carried out based on the perceptions of locals; such work is harder to perform in case of trees and tree alleys of course. Age and excellent condition of the plane tree, located in the yard of the electricity utility company, justifies the need for wider access from Csókakö-creek. Recreational and business functions can be developed along the bicycle ways in Erzsébet-grove. The following GI elements were identified as function deficient: Pethe Ferenc Jubilee park, Héviz-flow and Óberek canal and watercourses on the boundary of Zala and Somogy county.

Focusing on the CCAA is justified by the evaluation results as well. It was seen that the most densely built areas are located here, with very little green; its parks are function deficient and their quality is to be improved. Value 
of ecosystem services is weak in case of Zeppelin square and Kresz-park. Detailed proposals prepared for the CCAA are shown in Table 3.

Table 3. Recommendations for City Centre Action Area

\begin{tabular}{|c|c|c|}
\hline Area & Issue to be handled & Intervention \\
\hline $\begin{array}{l}\text { Environment of Main and Rákóczi } \\
\text { squares }\end{array}$ & Heat island effect & Increase of green areas \\
\hline $\begin{array}{l}\text { Arrays south of the Castle park, } \\
\text { environment of Kresz-park, Helikon } \\
\text { park and the so-called villa area }\end{array}$ & $\begin{array}{l}\text { Lack of network connections, } \\
\text { exposure to climate effects }\end{array}$ & $\begin{array}{l}\text { Quality improvement of } \\
\text { green areas, multilevel } \\
\text { vegetaion, tree care }\end{array}$ \\
\hline $\begin{array}{l}\text { Arrays along Helikon park, Kresz- } \\
\text { park and Fö street }\end{array}$ & $\begin{array}{l}\text { Function deficiencies, } \\
\text { conflictual usage }\end{array}$ & $\begin{array}{l}\text { Function extension, } \\
\text { diversification }\end{array}$ \\
\hline Helikon park, Zeppelin square & $\begin{array}{l}\text { Conflictual } \\
\text { transportation } \\
\text { deficiencies }\end{array}$ & Providing parking places \\
\hline $\begin{array}{l}\text { Arrays east from the Castle park to } \\
\text { Rákóczi square and arrays south of the } \\
\text { square }\end{array}$ & $\begin{array}{l}\text { Lack of network connections, } \\
\text { heat island effect }\end{array}$ & Deployment of tree alleys \\
\hline $\begin{array}{l}\text { Arrays east from the Castle park to } \\
\text { Rákóczi square, along Fö street }\end{array}$ & Exposure to climate effects & Water retention \\
\hline
\end{tabular}

However, our methodology strongly builds on existing national and international practice on monitoring GI element it is unique regarding the mixture of them and in the applied scale as well. The tree condition survey from Szaller (2013) did not published before as a part of a complex green infrastructure survey and the tree alley survey is a new development of the recent work. Although, park surveys still existing in Hungary and a detailed water surface survey is also available, researchers did not apply them as a part of such a complex survey. Also, the evaluation method of ecosystem services, that is suitable for wider social involvement was an important development of our work. Results of the survey can be well used in practice, and the methodology was designed to be future proof. Beside relying largely on the information of existing databases, the work includes an independent survey methodology as well. The formed GI system can be further developed by full and systematic assessment of each element and group. In the long term, creation of a downtown tree cadastral database is recommended, which includes one-by-one digitalization and assessment of trees (such database successfully integrated into tree care in Budapest or in other metropolis, like NYC, Melbourne. In smaller Hungarian towns the digitalization just has started). A more detailed mapping of outer downtown areas is also recommended to provide basis for measurement-based examinations, e.g. in the case of characterizing biodiversity. Measurement of environmental elements of the area should be monitored by remote stations, and results should also be incorporated in the characterization of the GI network, to get the fullest picture possible.

\section{References}

5t Építészeti és Városfejlesztési Kft. \& HÉTFA Research Institute. (2015). Keszthely város településfejlesztési koncepciója 2015-2030. Retrieved from https://www.keszthely.hu/webimages/files/Keszthely\%20Varos\%20Telepulesfejlesztesi\%20Koncepcioja $\% 2$ 02014-2030.pdf

Almási, B. (2007). A zöldhálózat tervezés metodikai fejlesztése Budapest peremterületének példáján, doktori értékezés, Budapesti Corvinus Egyetem Tájépítészet és Döntéstámogató Rendszerek, Budapest. p. 12-14.

Amati, M., \& Taylor, L. (2010). From green belts to green infrastructure. Planning Practice and Research, 25(2), 143-155. https://doi.org/ 10.1080/02697451003740122

Artmann, M., Bastian, O., \& Grunewald, K. (2017). Using the concepts of green infrastructure and ecosystem services to specify leitbilder for compact and green cities - the ex-ample of the landscape plan of Dresden, Germany. Sustainability, 9(2), 198. https://doi.org/ 10.3390/su9020198

Bartesaghi, K. C., Osmond, P., \& Alan, P. (2017). Towards a comprehensive green infrastructure typology: a 
systematic review of approaches, methods and typologies. Urban Ecosystems, 20(15-35). https://doi.org/20. 15-35.10.1007/s11252-016-0578-5.

Benedict, M. A., \& McMahon, E. T. (2006). Green Infrastructure: Linking Landscapes and Communities. Washington, DC: Island Press

Commission for Architecture and the Built Environment. (CABE) \& Natural England (2010). Building natural value for sustainable economic development-The green infrastructure valuation toolkit user guide. Retrieved from

http://www.greeninfrastructurenw.co.uk/resources/Green_Infrastructure_Valuation_Toolkit_UserGuide.pdf.

Common International Classification of Ecosystem Services. - CICES-V4-3 (2013). Retrieved from https://cices.eu/

Convention on Biological Diversity. (CBD) (2015). p. 3. Retrieved from https://www.cbd.int/doc/quarterly/qr-63en.pdf

Davies, C., MacFarlane, R., McGloin, C., \& Roe, M. (2010). Green Infrastructure Planning Guide. https://doi.org/10.13140/RG.2.1.1191.3688

Department for Communities and Local Government. (DCLG) (2008a). Planning Policy Statement 12: creating strong safe and prosperous communities through Local Spatial Planning. Retrieved from http://www.greeninfrastructurenw.co.uk/climatechange/doc.php?docID=166

Department for Communities and Local Government. (DCLG) (2008b). Eco-towns-Living a greener future. Retrieved from https://delta.bipsolutions.com/docstore/pdf/23080.pdf

European Commission. (EC) (2012). The Multifunctionality of Green Infrastructure. Retrieved from https:/ec.europa.eu/environment/nature/ecosystems/docs/Green_Infrastructure.pdf

European Commission. (EC) (2013). Green Infrastructure (GI) - Enhancing Europe's Natural Capital, $\mathrm{COM} / 2013 / 0249$ final

European Environment Agency. (EEA) (2014). Spatial Analysis of Green Infrastructure in Europe. Technical report No. 2/2014, Luxemburg, Retrieved from http://www.eea.europa.eu/publications/spatial-analysis-ofgreen-infrastructure/download.

Gill, S., Handley, J., Ennos, R., \& Nolan, P. (2009). Planning for green infrastructure: adapting to climate change. In: S. Davoudi et al. (Eds.) Planning for climate change: strategies for mitigation and adaptation for spatial planners. London: Earthscan, 249-261.

Green Infrastructure - Connected and Multifunctional Landscapes. (2009). Landscape Institute Position statement. Retrieved from http://www.landscapeinstitute.org/PDF/Contribute/GreenInfrastructurepositionstatement13May09.pdf

Haines-Young, R., \& Potschin, M. (2009). The links between biodiversity, ecosystem services and human wellbeing. In Raffaelli, D., \& Frid, C. (Eds.), Ecosystem Ecology: A New Synthesis. BES ecological reviews series. Cambridge:.CUP

HÉTFA Research Institute. (2017). Keszthely Zöldinfrastruktúra Fejlesztési- és Fenntartási Akcióterv 2017, Keszthely Város Önkormányzata, Keszthely

Hungarian Central Statistical Office. (2019). Detailed Gazetteer. Retrieved from http://www.ksh.hu/apps/hntr.telepules?p_lang=EN\&p_id=18421

Jámbor, I. (1982). Zöldfelület-rendezés, Budapest: Budapesti Kertészeti Egyetem,. pp. 8-9.

Jombach, S. (2014). Zöldfelület intenzitás állapota és változása 2010-2013 időszakban, Budapest XIII. kerület. Retrieved from https:/www.kozszolgaltato.bp13.hu/letoltes/20160327-zfi-elemzes-bp13-2010-2013-bce.pdf

Karhu, J. (2011). Green infrastructure implementation. Proceedings of the European Commission Conference, 19 November 2010, Brussels, Belgium: European Commission.

Koller és Társa Tervező Kft. (2001). Keszthely - Hévíz város-páros vizsgálatok. Pécs.

Koschke L., Fürst C., Frank S., \& Makeschin F. (2012). A multi-criteria approach for an integrated land-coverbased assessment of ecosystem services provision to support landscape planning. Ecological Indicators, 21(1) 54-66.

Lindholm, G. (2017). The implementation of green infrastructure: relating a general concept to context and site. 
Sustainability, 9(4), 610. https://doi.org/ 10.3390/su9040610

McDonald L. A., Allen W. L., Benedict M. A., \& O'Conner K. (2005). Green Infrastructure Plan Evaluation Frameworks. Journal of Conservation Planning, 1(1), 6-25.

McMahon E. T., \& Benedict M. A. (2002). Green Infrastructure: Smart Conservation for the 21st Century. Renewable Resources Journal, 20(3),12-17.

Mell I., Henneberry J., Hehl-Lange S., \& Keskin, B. (2013). Promoting urban greening: Valuing the development of green infrastructure investments in the urban core of Manchester, UK. Urban Forestry \& Urban Greening, 12(3), 296-306. https://doi.org/12. 296-306. 10.1016/j.ufug.2013.04.006.

Mell, I. C. (2017). Green infrastructure: reflections on past, present and future praxis. Landsc. Res., 42(2), 135145. https://doi.org/ 10.1080/01426397.2016.1250875

Natural England. (2009). Green Infrastructure Guidance. Retrieved from http://publications.naturalengland.org.uk/file/94026.

Natural England. (2011). 'Nature Nearby'-Accessible Natural Greenspace Guidance. Retrieved from http://webarchive.nationalarchives.gov.uk/20140605090108/http://publications.naturalengland.org.uk/file/9 5015.

Naumann, S., McKenna, D., Kaphengst, T., Pieterse, M., \& Rayment, M. (2011). Design, implementation and cost elements of Green Infrastructure projects. Final report to the European Commission, DG Environment, Contract no. 070307/2010/577182/ETU/F.1, Ecologic institute and GHK Consulting.

Oláh, A. B. (2012). A városi beépitettség és a felszintípusok hatása a kisugárzási hömérsékletre. doktori értekezés, Budapesti Corvinus Egyetem, Tájépítészeti és Tájökológiai Doktori Iskola, Budapest. p. 17.

Opdam, P., Steingro"ver, E., \& Rooij, S.V. (2006). Ecological networks: a spatial concept for multi-actor planning of sustainable landscapes. Landscape and Urban Planning, 75(3-4), 322-332. https://doi.org/ 10.1016/j.landurbplan.2005.02.015

Protected Natural Values of Hungary. Retrieved from termeszetvedelem.hu.

Reimer, M., \& Rusche, K. (2016). Green Infrastructure - an Important Element in Strategic Urban Planning. In IGLUS (Ed.), GIPC - Governance, Innovation and Performance in Cities. pp. 6-8.

River Basin Management Plan of Lake Balaton. Retrieved from http://www2.vizeink.hu/ and www.kdtvizig.hu/

River Basin Management Plan of Zala River. Retrieved from http://www2.vizeink.hu/ and www.kdrtvizig.hu/

Schröter-Schlaack, C., \& Schmidt, J. (2015). Ökosystemdienstleistungen grüner Infrastrukturen: Erfassung, Bewertung und Inwertsetzung. RaumPlanung, 4(17-21).

Seiwert, A., \& Rößler, S. (2020). Understanding the term green infrastructure: origins, rationales, semantic content and purposes as well as its relevance for application in spatial planning. Land Use Policy, 97. https://doi.org/ 104785. 10.1016/j.landusepol.2020.104785

Siemens. (2009). The European Green City Index-Assessing the environmental impact of Europe's major cities. Munich, Germany: Siemens AG. Retrieved from https://assets.new.siemens.com/siemens/assets/api/uuid:fddc99e7-5907-49aa-92c4610c0801659e/european-green-city-index.pdf

Siemens. (2012). The Green City Index-A summary of the Green City Index research series. Munich, Germany: Siemens AG. Retrieved from https://assets.new.siemens.com/siemens/assets/api/uuid:cf26889b-3254-4dcbbc50-fef7e99cb3c7/version:1578486906/gci-report-summary.pdf

Sylwester, A. (2009). Green infrastructure: supporting connectivity, maintaining sustainability. Brussels: European Commission

Szabó, I. (2013). Keszthely növényvilága. Keszthely: Keszthelyi Környezetvédő Egyesület. Retrieved from http://korke.ayaclab.com/doc/Keszthely_novenyvilaga.pdf

Szaller V. (2013). Útmutató a fák nyilvántartásához és egyedi értékük kiszámitásához. Magyar Faápolók Egyesülete. $\quad$ Retrieved from http://www.faapolok.hu/wpcontent/uploads/2014/05/Fakataszter-\%C3\%9Atmutat\%C3\%B3-20131.pdf

Tajima, K. (2003). New Estimates of the Demand for Urban Green Space: Implications for Valuing the Environmental Benefits of Boston's Big Dig Project. Journal of Urban Affairs, 25, 641-655. https://doi.org/ 
10.1111/j.1467-9906.2003.00006.x.

The Landscape Institute. (2009). Green infrastructure: connected and multifunctional landscapes. London: The Landscape Institute, Retrieved from https://landscapewpstorage01.blob.core.windows.net/wwwlandscapeinstitute-org/2016/03/GreenInfrastructurepositionstatement13May09.pdf

Town and Country Planning Association (2008). The Essential Role of Green Infrastructure: Eco-Towns Green Infrastructure Worksheet. Retrieved from http://www.tcpa.org.uk/data/files/etws_green_infrastructure.pdf.

Town and Country Planning Association. (TCPA) (2008). The Essential Role of Green Infrastructure: Eco-towns Green Infrastructure Worksheet. Advice to Promoters and Planners. London: Town and Country Planning Association, Retrieved from https://www.tcpa.org.uk/Handlers/Download.ashx?IDMF=dd06b21d-6d414c4e-bec5-4f29a192f0c6.

Varsás Környezetvédelmi és Szolgáltató Bt. (2017). Keszthely város környezetvédelmi programja. Retrieved from https://www.keszthely.hu/ftp/Koncepciok_uj/K\%c3\%b6rnyezetv\%c3\%a9delmi\%20koncepci\%c3\%b3/2017 _Keszthely_Kornyezetvedelmi_program_2017-2022.pdf

\section{Authors}

Krisztina Filepné Kovács, associate professor at Department of Landscape Planning and Regional Development, Faculty of Landscape Architecture and Urbanism, Szent István University, Budapest, Hungary, Villányi út 35-43, K Building, H-1118, Budapest, Hungary, Filepne.Kovacs.Krisztina@tajk.szie.hu

Vera Iváncsics, Phd student at Department of Landscape Planning and Regional Development, Faculty of Landscape Architecture and Urbanism, Szent István University, Budapest, Hungary, Villányi út 35-43, K Building, H-1118, Budapest, Hungary, Ivancsics.Vera@phd.uni-szie.hu, https://orcid.org/0000-0002-88294060

\section{Copyrights}

Copyright for this article is retained by the author(s), with first publication rights granted to the journal.

This is an open-access article distributed under the terms and conditions of the Creative Commons Attribution license (http://creativecommons.org/licenses/by/4.0/). 